\title{
Football and national power: a theoretical framework applied to China and Argentina
}

1. Sun Yat-sen University. Researcher at the Center for Latin American Studies Guangzhou/China. ORCID: 0000-0002-4304-383

2. Sun Yat-sen University.Researcher at the Center for Latin American Studies Guangzhou/China. ORCID: 0000-0002-1176-911X

\section{Futebol e poder nacional: um referencial teórico aplicado à China e Argentina}

\section{D0I: 10.5752/P.2317-773X.2018v6.n3.p26}

Daniel Morales Ruvalcaba ${ }^{1}$

Zhongli Zhang ${ }^{2}$

Received in december 21, 2017

Accepted in april 04, 2018

\section{Abstract}

Football has become a global phenomenon, but there are relatively few studies that come from International Relations. This document explores the contributions that football makes to the national power of States through three hypotheses: 1) national power is affected by all types of human activities, including sport; 2 ) football, as human activity, promotes national power; 3 ) football is conditioned by the world system and reproduces its dynamics. To verify these hypotheses, this paper presents a theoretical framework to analyze the contribution of soccer to national power; later implements this theoretical framework to study the football potentiality of the regional powers of the semi-periphery; and, finally, identifies the relations in football between two outstanding actors: Argentina and China.

Keywords: National power, football, world-system, Argentina, China.

\section{ResUMO}

O futebol tornou-se um fenômeno global, mas há relativamente poucos estudos das Relações Internacionais que abordam o problema. Este documento explora as contribuições que o futebol faz para o poder nacional com base em três hipóteses: 1) o poder nacional é afetado por todos os tipos de atividades humanas, incluindo esportes; 2) o futebol, como atividade humana, promove o poder nacional; 3) o futebol é enquadrado no sistema mundial e o reproduz. Para verificar essas hipóteses, este artigo apresenta um quadro teórico que analisa a contribuição do futebol para o poder nacional; em seguida, implementa esse quadro para o estudo do potencial de futebol das potências regionais da semiperiferia; e, finalmente, são identificadas as relações no futebol entre dois jogadores proeminentes: Argentina e China.

Palavras chave: Poder nacional, futebol, sistema-mundial, Argentina, China. 
Introduction

Today, football has become a global phenomenon, largely due to the development of telecommunications and the involvement of multinational brands, but also thanks to the monopolistic and lucrative role played by FIFA (BONIFACE, 2006; EISENBERG, 2006a; DIETSCHY, 2013).

While it is true that a number of scholars have ventured into the sociological study of football -especially since the construction of national representations and identities (HADAS, 2000; MARSCHIK, 2001; BRADLEY, 2002; KARUSH, 2003; DARBY, 2013) - there are relatively few studies that come from International Relations (EISENBERG, 2006b), that is, from an optic considering States, international organizations and multinational corporations as fundamental players in this global sport. It is argued here that football is a phenomenon that merits further examination from International Relations (IR), not only because of its growing importance in world affairs but also because it is an activity that paradoxically fosters globalization, regionalism and nationalism simultaneously.

Under this prism of analytical possibilities, this document is framed in the contributions that football makes to the national power of States and, for this, the following working hypotheses are drawn here: 1) national power is a multidimensional, recursive and dynamic phenomenon that is affected by all types of human activities, including sport; 2) football has become a global phenomenon which promotes national power; 3 ) football is conditioned by the world-system and reproduces its dynamics.

It should be noted that, because of its scope, volume and complexity, football is presented today as a phenomenon that must be studied from the IR, but also it poses theoretical and methodological challenges to the discipline. In the current international context of the rise of nationalisms and skepticism in the face of globalization, this article seeks to re-evaluate macro approaches used by IR, which today can be very useful for a better understanding of football as a global phenomenon.

This paper is organized in three parts: the first presents a theoretical approach to analyze the contribution of soccer to national power, a proposal that is supported by extensive empirical information; the second part implements this theoretical framework to study the football potentiality of the regional powers of the semi-periphery, emphasizing two cases: Argentina, a "football world power", and China, the main emerging power of the last two decades and the only one that aspires decisively to reach a major role in this sport the next years; and the third part identifies the relations of exchange and cooperation between China and Argentina, which are shown as an exceptional but with possibilities of further deepening.

Football in the national power of the States

One of the recent approaches to the national power of a state has been proposed by Morales, Rocha and Duran, who define it as "a product of the multidimensional, dynamic and recursive combination of material capacities (MC), semi-material capabilities (SMC) and immaterial capacities (IMC), which is expressed as a result at a given historical 
moment of the development of States in the international political system" (MORALES; ROCHA; DURÁN, 2016, p.83). The most relevant of his perspective on national power is that, in addition to considering it as a three-dimensional phenomenon -which advances the two-dimensional type hard /soft power perspective- it is sustained on the concept of national capacities, which are also organized in three dimensions and based on indicators that are clearly measurable. As a result of their conceptualization, the authors add that national power is thus "the relative potential -no capacity is measured in absolute terms- and relational -no capacity develops in isolation- that defines position (structural position), capacity of action (what they can or cannot do), projection (possible geoeconomic and geopolitical scopes) and attraction (diffusion and geocultural projection) of a country in the ensemble of States that make up the inter-state international system" (MORALES; ROCHA; DURÁN, 2016, p.84). Now, in what way is football articulated with the power of a nation-state?

Soccer is a highly complex and multidimensional global phenomenon since it is not limited to the sociocultural sphere -with millions of people practicing it and many others who use it as mechanisms for the expression or reaffirmation of their identities- but it directly impacts the economy and demands of the political action of the States (TORGLER, 2004; ALLMERS; MEANNIG, 2009; DUBAL, 2010; LEVERMORE, 2011). However, since its origins the State has acted as a political entity engaged in the maintenance and defense of sovereignty which has historically increased secularization, exalted the notion of non-interference in internal affairs and fed back the so-called raison d'État. Like other human activities, being permeated by the raison d'État, football becomes a mechanism for the consolidation of the State, the promotion of national interests and the increase of national power.

Indeed, due to the wide range of social segments and economic sectors involved in soccer, it is possible to affirm that this sport has repercussions in each of the three categories of national capacities identified before.

The football material capacities and its contribution to economic-military power

Material capacities are related to economic and military indicators (MORALES; ROCHA; DURÁN, 2016, p.83). In this sense, the elements of football that would refer to the material capacities of a State would be those related to the economic size, financial preponderance and relative weight that has reached a national soccer league in the world. This would be observable through: the cost of the team, the total value of the league and the price of the players who play in them (estimated through the transfer value).

According to Forbes, the cost of a football team is determined by four categories of income: "those generated on the day of the game, broadcast, commercial and brand" (FORBES, 2016). Based on this, it was established that the ten most valuable soccer teams in the world in 2016 were: (i) Real Madrid/Spain, US\$3.65 billion, (ii) Barcelona/Spain, US\$3.55 
billion, (iii) Manchester United/England, US\$3.32 billion, (iv) Bayern Munich/Germany, US\$2.68, (v) Arsenal/England, US\$2.02 billion, (vi) Manchester City/England, US\$1.92 billion, (vii) Chelsea/England, US\$1.66 billion, (viii) Liverpool, US $\$ 1.55$ billion, (ix) Juventus/Italy, US $\$ 1.3$ billion, (x) Tottenham/England, US\$1.02 billion. It should be noted here that all the most expensive equipment is in developed countries, mainly in the United Kingdom, Spain, Germany, France and Italy.

However, the cost of these teams contributes to raising the total value of the leagues where they participate. According to the agency Transfermarkt-specialized in information from the world of football- there are only eleven national leagues that exceed the value of 500 million euros: (i) Premier League/England, €5.42 billion, (ii) La Liga/Spain, €3.5 billion, (iii) Serie A/Italy, €3.13 billion, (iv) Fußball-Bundesliga/Germany, €2.71 billion, (v) Ligue 1/France, $€ 1.82$ billion, (vi) Liga NOS/Portugal, $€ 862$ million, vii) Série A/Brazil, €810 million, (viii) Süper Lig/Turkey, €786 million, (ix) Premier League/Russia, $€ 714$ million, (x) Liga MX/Mexico, $€ 592$ million, (xi) Primera División/Argentina, €556 million.

Undoubtedly, the cost of football teams and the value of national leagues depends, to a large extent, on their players. But how do you calculate the value of a football player? Based on the study of almost 2,000 paying fee transfers, the CIES Football Observatory -a Swiss independent center specialized in the statistical analysis of football- developed a powerful approach to estimate the transfer value of professional football players. The CIES academic team consider ten indicators in three groups: first group, characteristics of players such; second, players' performances; and, third group, level of the leagues where they play (Poli, et al., 2016). Now, something that is important to mention is that all the players with the highest value estimated by CIES play in the most expensive European leagues, but almost a third (32\%) come from developing countries, mostly from South America (CIES FOOTBAL OBSERVATORY, 2017; POLI; RAVENEL; BESSON,2015).

\section{The football semi-material capacities and its contribution to socio-institutional power}

The strength of a state (economic-military power) does not automatically translate into high standards of development and well-being for its population. To better understand these capabilities, it is necessary to look at a second dimension of national power. Semi-material capacities are related to the socio-institutional power of a State, that is, in the advancement of a State through the prosperity of its population and the development of its national institutions (MORALES; ROCHA; DURÁN, 2016, p.83). In the same way that indicators were mentioned to talk about the material capabilities of football in a country -and with it, the economic and financial preponderance of a soccer league- it is necessary to point out other items that refer to the quality of this sport. In that tenor, the elements that could refer to the semi-material capacities are: number of teams playing in each national league, level of national leagues and competitiveness of their teams in the world cup. 
The first thing to consider is the number of teams competing in each of the leagues of the highest level -that is, first division or its equivalent- per country. This is relevant, because the number of teams in the first division is directly related to the amount of population of a country and with the popularity of football in that place. In this way, it can be noted that the countries with the first division football leagues with as many teams are: (i) Argentina with 28 teams; (ii) United States with 22; (iii) countries with 20 teams are Brazil, Colombia, England, France, Italy and Spain; and, (iv) with 18 teams are, Egypt, Germany, Indonesia, Japan, Mexico, Netherlands, Portugal, Thailand, Turkey and Venezuela. As can be seen, several of the national leagues listed here are also those that were previously identified as the most valuable. But, the more teams competing, the higher the quality of the league? Not necessarily.

It is important to weigh the competitiveness of each league -and not only its economic value according to material capabilities- since Gasparetto and Barajas, following the classical theory proposed by Rottenberg (1956), argue that "fans are more interested in balanced tournaments" or competitive (GASPARETTO; BARAJAS, 2016, p.290). In accordance with the International Federation of Football History and Statistics (IFFHS) -an organization founded on March $27^{\text {th }}, 1984$ and focused on documenting the history and records of FIFA- the ranking of the strongest national league in 2015 was (IFFHS, 2016a): 1) Spain, 2) Italy, 3) Germany, 4) Argentina, 5) France, 6) Brazil, 7) England, 8) Portugal, 9) Belgium, 10) Russia. With the study of Gasparetto and Barajas it is possible to corroborate the good competitive balance of the leagues identified by the IFFHS.

Now, what is most relevant to theorizing about the contribution of football to national power is that the leagues mentioned here are those that traditionally generate more interest at the global level not only in terms of level of competition but also in the quality of clubs that participate there. According the IFFHS, the club world ranking in 2015 was (IFFHS, 2016b): $1^{\text {st }}$ FC Barcelona/Spain, $2^{\text {nd }}$ Juventus FC/Italy, $3^{\text {rd }}$ SSC Napoli/Italy, $4^{\text {th }}$ FC Bayern München/Germany, $5^{\text {th }}$ Paris Saint-Germain FC/France, $6^{\text {th }}$ Real Madrid CF/Spain, $7^{\text {th }}$ Club Independiente Santa Fe/ Colombia, $8^{\text {th }}$ ACF Fiorentina/Italy, $9^{\text {th }}$ River Plate/Argentina, $10^{\text {th }}$ VfL Wolfsburg/Germany. Of course, most of the top clubs considered by IFFHS also compete in the most competitive leagues in the world: $2 / 3$ of the top 50 teams play in the leagues of the countries mentioned in the previous paragraph.

The football immaterial capacities and its contribution to communicative-cultural power

Immaterial capacities are directly related to the communicativecultural power (MORALES; ROCHA; DURÁN, 2016, p.83). In this sense, the elements of soccer that would reflect the material capacities of a State would be those linked to the prestige, cosmopolitanism and fame of each national league with respect to their peers. To appreciate this, it is relevant to review: brand value soccer's team, broadcasting rights and the number of foreigners in each league. 
Brand Finance, founded in 1996 and headquartered in London, is the world's leading independent branded business valuation and strategy consultancy. This agency considers that "football clubs are made up of a mixture of fixed tangible assets (stadium, training ground) and disclosed intangible assets (purchased players) with brand value, internally developed players $\&$ goodwill making up the difference to provide the combined clubs value" (BRAND FINANCE GROUP, 2012, p.18). In one of its most widespread and complete reports, published at 2012, Brand Finance presented the brand value of 190 football clubs, in a range of US\$853 million (Manchester United FC, England) to US\$3.5 (Associação Portuguesa, Brazil). The most relevant of the Brand Finance report is that it identifies, on the one hand, the number of clubs per country within the "top 190 " within the most valuable brands in football and, on the other hand, the total value resulting from the sum of the most valuable brands per country. Regarding the sum of the value of clubs per country (only of the brands listed in the "top 190"), the following order appears: 1) Premier League/England, 2) Fußball-Bundesliga/Germany, 3) La Liga/Spain, 4) Serie A/Italy, and 5) Série A/Brazil. However, when looking at the number of clubs per country within the "top 190" it is revealing that: (i) Japan has 23 clubs on that list, (ii) Brazil with 18, (iii) United States with 17, (iv) Mexico with 13, (v) England with 12. From this, it is possible to point out that although the teams of developed country leagues have the highest value as brands worldwide, in developing countries the brand value is more moderate but with a much larger number of clubs, aspect that increases its future potential.

Now, a strategy of the clubs to generate proximity and achieve penetration in specific national or regional markets, is to proceed to the recruitment of prominent soccer players but from those places. In other words, here is argued that the recruitment of foreign players not only responds to a logic of the increase in the competitiveness of the sport, but is also due to historical factors, geographical and cultural approach (POLI, 2006; TAYLOR, 2006). In fact, the recent patterns of soccer globalization have made this sport "an excellent arena in which to examine migration patterns, ideas of identity and the connections between people and place" (STOREY, 2011, p.94) which promotes cosmopolitism (ZOLO, 2000; BECK, 2002; GIRI, 2006) and the super-diversity of societies (VERTOVEC, 2007; MEISSNER; VERTOVEC, 2015). According to the reasons given here, national leagues with more foreign players reach a greater competitiveness, but especially a greater global projection. In this sense, the data provided by Transfermarkt is again very useful, since it allows to see which are the most cosmopolitan or super-diverse leagues in the world, with most of their players with foreign nationality (that is, more than 50\%): 1) Premier League/England) 67\%; 2) Liga NOS/Portugal 58.5\%; 3) Jupiler Pro League/Belgium 58.5\%; 4) First Division/Cyprus 57.9\%, 5) Serie A/Italy 53.5\%, 6) Gibraltar Premier Division/Gibraltar 53.4\%, 7) BGL Ligue/Luxemburg 53.0\%, 8) Süper Lig/Turkey $52.8 \%$, 9) Bundesliga/Germany 52.5\%, 10) MLS/United States 52.3\%, 11) Ligue $1 /$ France $50.1 \%$.

As for the broadcasting rights, it is possible to find some studies that have addressed the issue (FALCONIERI; SÁKOVICS; PALOMINO, 
2004; EVENS; LEFEVER, 2011; GORTAZAR, 2012). To a large degree, the debate has been focused on the results obtained between the individual management of the broadcasting rights by each team or the collective bargaining of the same by the league. Apart from this discussion, the fact is the income of the broadcasting rights in football has increased -as has been described above- extraordinarily in recent years, not only for FIFA but also for national leagues and clubs. It's important to consider the sale of broadcasting rights because, according to Christian Huveneers, "the sports market therefore brings together different groups of customers, and different avenues of income. In terms of modern economic theory, the sports market is thus a multi-sided or platform market-i.e. a market where platforms bring together different groups of customers" (HUEVENNERS, 2014, p.2). It should be noted that while in developing country leagues each club manages its broadcasting rights individually, in developed countries the teams negotiate collectively in such a way that, according to Forbes, these are the most important values of transmission per season in recent years (FORBES, 2017): i) Premier League/England, US $\$ 2.63$ billion, ii) Serie A/Italy, US\$1.13 billion; iii) Bundesliga/Germany, US\$790 million, iv) Ligue 1/France, US\$739 million; v) La Liga/Spain, vi) US\$706 million, vii) Turkish Super League/Turkey, US\$489 million; viii) MLS/United States, US\$90 million, ix) Dutch Eredivisie/Netherlands, $\$ 87$ million. In such a growing and diverse market, a good coverage and transmission guarantees the media positioning of the clubs worldwide, which increases its brand value, object of study of Brand Finance.

As it is very difficult to calculate the value of broadcasting costs of developing country leagues (since each team manages its own broadcasting rights), then another indicator to see the prestige of a country's football is through its national teams: the most renowned teams will always be the most followed and seen in international competitions. To weight this, can be consulted FIFA World Ranking, specifically the average position since the creation of this ranking (FIFA, 2017).

\section{Recursion of football's capacities around national power}

Coremberg, Sanguinetti and Wierny consider that the benefits of football to society are enormous: "strengthens national identity and unity, provides the possibility of generate a good image of the country when organizing an international event or its teams achieve good results in international tournaments, contributes to the dissemination of values that promote work and discipline and, finally, the practice of football can be a strategy for the promotion of health and the improvement of the quality of life of the inhabitants" (COREMBERG; SANGUINETTI; WIERNY, 2015, p.13). As previously shored, football externalities are also linked to national power as this is a multidimensional, recursive and dynamic phenomenon that is affected by all types of human activities.

With the information compiled, it is possible to point out how the football business is redundant in the accumulation of wealth: the soccer clubs that generate more income have the resources to hire the players of greater value and world-wide fame (that in many occasions 
come from developing countries); however, the money spent to buy the most expensive players in the world recovers widely, as these clubs benefit collectively by competing with other teams that have "superstars" of similar fame. This lucrative business takes place essentially in developed countries, allowing the governments of these countries to attract global resources that, in addition to benefiting companies linked to football, ends up providing extraordinary resources to the States, benefiting their material capacities.

In addition, it is observed that the quality of football is directly linked to the semi-material capacities of the countries since, on the one hand, for a competitive league to be possible, a more or less numerous population is needed (with medium levels of social welfare and efficient institutions that guarantee and promote the performance of public activities, such as sport); but on the other hand, once a certain quality is achieved in soccer leagues, these generate economic resources that end up benefiting players, clubs, entrepreneurs, industries linked to football and, in short, the national society as a whole. All this, finally, overflows populations, benefits the semi-material capacities and increases the socioinstitutional power of States.

By last, football clubs with foreign players of the highest level not only increase their aptitude to sell shirts all over the world and to fill stadiums where they present their "superstars", but also translate into income from advertising and marketing product sales derived from interest for sponsors looking for very specific national or regional markets. All above turns out as an increase in fame and prestige for national leagues and, finally, the communicative-cultural power of the States.

No sport like football had transcended to be not only a healthy and playful human activity, but also a spectacle, business and passion with such diffusion and magnitude. In that sense, football has become a global phenomenon that represents multi-million-dollar deals, world fame, international influence, prestige, etc., all of which certainly contributes to national power.

The heterogeneity of football in the semi-periphery countries

Football business has gone against the current in the financial crisis in 2008. At that moment, many countries were stuck in the economic recession, but the income of FIFA showed an exponential growth, averagely 15\% from 2006 to 2015 (FIFA, 2016). Yet, same as other industries, football can't make itself escape from the logic and the structure of the contemporary capitalist world system, which in fact is based on two major dynamics: the first one corresponds with the unequal distribution of gains between different areas: core, semi-periphery and periphery (WALLERSTEIN, 1974; TAYLOR; FLINT, 2002, p.20-22); the second one is about the slow positioning of Asia as a new world economic center of $21^{\text {st }}$ century (ASENIERO, 1996; BEESON, 2009; WALLERSTEIN, 2010). What interest here, is to emphasize the heterogeneity of the semi-periphery, but in the field of football. Before, a brief indication about the center and the periphery. 
The central countries are those that stand out not necessarily for possessing the highest material capacities, but for concentrating the higher semi-material capacities -constables in the high levels of well-being- and holding significant immaterial capacities for their ideologicalcultural projection in the system. This is due, among other reasons, to the fact that their economies are exporters of goods with high added value and are immersed in the so-called third industrial revolution, are headquarter to very important financial centers and stock exchanges, have many transnational corporations and have significant control over global value chains, their international reserves are large, their powerful armies, their influential media and their preponderant geocultures. In terms of football, they are the owners of the football league matches which are the richest and the most powerful. In fact, from the theorization and the indicators presented in the previous section, it is possible to verify that the central States are the main circuits of football in what accumulation of wealth, competitiveness and prestige refers, primarily England, Germany, Spain, France and Italy; and, to a lesser extent, the Netherlands, Portugal and Belgium. All of these are extremely powerful in the field of football, whose power results from the simultaneous combination of both material capacities (here are the most expensive teams in the world, their national leagues are the most valuable and have football players best quoted), as semi-material capacities (their tournaments have a large number of teams, their national leagues are considered the most competitive in the world and the teams that play there are considered the strongest) and immaterial capacities (they have the most valuable soccer brands, a very high percentage of their players come from overseas and their broadcasting rights have reached the highest values and the most broadcasting). It should be clear that not all core states are powers in terms of football -consider with the great exception of the United States (MARKOVITS, 1990) - however, it is clear that the main dynamics of football occur in the core states and, with their mechanics, the centrality of these countries in the world-economy. As anticipated, the concentration of wealth, competitiveness and prestige in the domain of football occurs in the core states.

At the opposite end is the periphery. The genealogy of the peripheral states goes back to the processes of colonization and exploitation intrinsic to the expansion of capitalism from its origins to the present day. In fact, it was especially between the sixteenth and nineteenth centuries that colonial states violently introduced the peoples of the periphery into the capitalist world-economy and -through exploitation- dismantled many of their development potential, all of which has caused that the peripheral nations failed to define their own model of development and simply try to imitate the steps followed by the central States for their industrialization. Thus, peripheral economies have been distinguished by their specialization in economic sectors producing raw materials with low added value, due to their incipient industrial sector and low technological level, due to their fragile and cyclical growth, and to present serious external debt problems. Its dependent insertion in the world economy has been the cause and effect of the conditions of unrest that predomi- 
nate in the periphery, that is, of societies where wages are precarious, little is invested in social programs, high levels of corruption persist and violence, social inequality is high and there is escape from those human talents that come to prosper. In general, the lack of socio-institutional power becomes a brake on the development of economic-military and communicative-cultural power. All this reduces presence to the peripheral countries in the world and makes them in States particularly vulnerable to the pressures of the core and semi-peripheral powers. However, within this large and numerous area, there are some that stand out for their relative advancement and proximity to the semi-periphery, these are the subregional powers (MORALES; ROCHA; DURÁN, 2016; TZILI, 2017; INIIGUEZ-TORRES, 2017). In terms of football, the peripheral countries that highlight in this sport are, in the following order, Liga Aguila/ Colombia, UPL/Ukraine, Persian Gulf Pro League/Iran, Egyptian Premier League/Egypt and Uzbek Oliy League/Uzbekistan. They stand out because of the relatively large number of teams competing in their first division leagues, the high international competitive level of certain local teams, the inclusion of some of their teams (only a few) in the "top 190 " football brands and the value of some its native players have reached in the transfer market. Certainly, the periphery remains sidelines of the world-economy and contributes specially with human resources that are appropriated by the core and the semi-periphery (POLI, 2006; DARBY, 2007; POLI; RAVENEL; BESSON, 2015).

However, the semi-periphery is not simply a residual category that covers the dichotomous gap existing between the notions of center and periphery but refers to a specific number of states (just under thirty) with their own characteristics. Among these, it is possible to mention that these States occupy an intermediate structural and functional position; maintain geographic contiguity with both central and peripheral states; which were colonized by central states, but maintained relatively greater margins of autonomy than those on the periphery; their economies are in the process of industrialization; their administrative apparatus are in the process of modernization; their societies show high socio-economic inequality and their internal regions exhibit a great disparity in their levels of development; they project attractive and influential geocultures but are far from dominant; they are at the same time expelling migrants, transit territories and recipients of immigrants, displaced persons, refugees, exiles and who have left their homes due to violence or need; contain deeply discordant and volatile social dynamics; and, they are relevant -although not directors- in international governance.

It should be noted that the intermediate position of the semi-periphery in the world system is both economic, social and cultural: in economic terms the semi-periphery maintains stronger ties with the center, since it depends relatively on its markets, companies and foreign exchange; however, in general terms, the semi-periphery retains a level of sociocultural approach closer to the periphery due to its geographic contiguity and historical interpenetration. In this sense, the semi-periphery is highly important because it possesses the most significant transforming potential for the system, since it is the locus of great discordant social forces 
and where transcendent political movements emerge (WALLERSTEIN, 2003; CHASE-DUNN, 1990; TERLOUW, 2003). The most prominent states in the semi-periphery are the so-called regional powers (NOLTE, 2006; FLEMES, 2007; HURRELL, 2010; MORALES; ROCHA; VARGAS, 2013) and these are: China, Russia, Brazil, Saudi Arabia, México, India, Turkey, Poland, Argentina and South Africa.

In general terms, all these countries stand out for their enormous potential for football because:

- Material capacities and its contribution to economic-military power: certainly, none of the teams in these countries are in the Forbes "top 20" list of most valuable football clubs, but in the majority of them there are clubs that exceed the cost of $€ 50$ million; with the sole exception of India, the value of their first division leagues exceeds $€ 100$ million; several of these countries are not only the birthplace of great "football stars" with very high values in the transfer market, but also are exporters of players for the rest of the world.

- Semi-material capacities and its contribution to socio-institutional power: with the only exceptions of Saudi Arabia and India, the first division leagues of these countries are robust because they compete in at least 16 teams, which contributes to receiving players from the periphery and serving, in some cases, as shop window for teams from core states; with the exceptions of China, South Africa and India, the competitiveness of the national leagues in these countries is relatively high because they are among the strongest 30; and, again with the exceptions of South Africa and India, all these countries have at least one soccer team that is among the strongest 100 .

- Immaterial capacities and its contribution to communicative-cultural power: with the exception of India, all countries have at least one football club that is in the "top 190" of the most valuable brands in this field; although it is difficult to estimate the total value of the broadcasting rights of their leagues, the national teams of these countries expectation around the world and are often rivals to win in regional competitions; and, in contrast to the competitions of the core states, the first division leagues in regional powers are less cosmopolitan and more nationalistic, to foster the generation of national talent.

Despite the relative strength of these countries in the field of football, it is also necessary to emphasize the heterogeneity that exists among them. As can be seen in the Table 1. The thrustfulness of football in regional powers, there is a great disparity not only of the strength, quality and prestige in the football of these countries but the contribution that this sport makes to their national power is also very unequal: at the top of the table, are Brazil and Argentina, countries with a huge football tradition, that have achieved great feats and have contributed -and still do- with great athletes in this sport, in synthesis "football world powers" but always with the constraints of its semi-peripheral nature; in the second quartile 
of the table, Turkey, Russia, Mexico and Poland, countries that although they have not reached the prowess of the previous ones (a huge difference, is that they have never been world champions), enjoy a football tradition also important and they have an imposing regional presence in terms of football; in the third quartile, Saudi Arabia and China, two emerging powers of the late twentieth century, with a short tradition in modern football, but who have great aspirations in this sport and are betting very strongly on it; and at the bottom of the table, South Africa and India, regional powers that for historical, cultural and even structural reasons, still do not stand out in this sport.

TABLE 1 - The thrustfulness of football in regional powers

\begin{tabular}{|c|c|c|c|c|c|c|c|c|c|c|}
\hline & $\begin{array}{l}\text { Teams } \\
\text { value }^{\mathrm{a}}\end{array}$ & $\begin{array}{l}\text { League } \\
\text { value }^{b}\end{array}$ & $\begin{array}{c}\text { "Top 11" } \\
\text { national } \\
\text { players } \\
\text { valuec }^{c}\end{array}$ & $\begin{array}{c}\text { Number } \\
\text { of } \\
\text { teams }^{\mathrm{d}}\end{array}$ & $\begin{array}{c}\text { Strongest } \\
\text { league }^{\mathrm{e}}\end{array}$ & $\begin{array}{c}\text { Strongest } \\
\text { teams }\end{array}$ & $\begin{array}{l}\text { Brand } \\
\text { value }^{f}\end{array}$ & $\begin{array}{c}\text { Foreigners } \\
\text { in national } \\
\text { league }^{b}\end{array}$ & $\begin{array}{c}\text { Ranking } \\
\text { national } \\
\text { teams }^{\mathrm{g}}\end{array}$ & TOTAL \\
\hline Brazil & 8 & 9 & 9 & 8 & 9 & 10 & 10 & 1 & 10 & 74 \\
\hline Argentina & 7 & 6 & 10 & 10 & 10 & 9 & 7 & 2 & 9 & 70 \\
\hline Turkey & 10 & 10 & 7 & 7 & 7 & 7 & 4 & 10 & 6 & 68 \\
\hline Russia & 9 & 8 & 5 & 6 & 8 & 8 & 6 & 8 & 7 & 65 \\
\hline Mexico & 6 & 7 & 6 & 7 & 6 & 6 & 9 & 9 & 8 & 64 \\
\hline Poland & 3 & 4 & 8 & 6 & 4 & 4 & 2 & 7 & 5 & 43 \\
\hline China & 5 & 5 & 2 & 6 & 3 & 3 & 8 & 4 & 2 & 38 \\
\hline Saudi Arabia & 4 & 3 & 3 & 5 & 5 & 5 & 5 & 5 & 3 & 38 \\
\hline South Africa & 2 & 2 & 4 & 6 & 2 & 2 & 3 & 3 & 4 & 28 \\
\hline India & 1 & 1 & 1 & 3 & 1 & 1 & 1 & 6 & 1 & 16 \\
\hline
\end{tabular}

Own elaboration table.

a. The Forbes' list was expanded with the Transfermarkt GmbH \& Co data (2017). For this item, only football teams worth more than 50 million euros have been counted.

b. Transfermarkt GmbH \& Co data (2017).

c. The information generated by CIES Football Observatory has been complemented with Transfermarkt $\mathrm{GmbH} \&$ Co data (2017). For the calculation of this item, has been considered the value of the "top 11" of the most expensive soccer players in each country, regardless of the league where they compete.

d. From the amount of equipment existing in the first division leagues of the world, the following values were assigned: 28 teams $=10$ points, 22 teams $=9$ points, 20 teams $=8$ points, 18 teams $=7$ points, 16 teams $=6$ points, 14 teams $=5$ points, 12 teams $=4$ points, 10 teams $=3$ points, 9 teams $=2$ points, 8 teams or less $=1$ point

e. IFFHS reports (2016a; 2016b; 2017). The score was assigned decreasingly (staring from 10) according to the ranking of the league or the positioning of their teams.

f. From 10 to 1, decreasing values were assigned according to the number of teams per country included in the "top 190" brand values (BRAND FINANCE GROUP, 2012).

g. From 10 to 1, were assigned decreasing values according to the FIFA World Ranking, specifically the average position since the creation of this ranking (FIFA, 2017).

Of all the previous countries and among its possible links, the SinoArgentine relationship is the one that is shown as the most exceptional. What is this about? As already noted, China is the only emerging power that has made explicit its ambitious aspirations in football (BARDON; BLACK, 2008; TIEN-CHIN; BAINER, 2010; CORNNELL, 2017) and, the 
3. In addition to Brazil and Argentina the Chinese Super League, only has record of the participation of five players from Poland, three from Turkey and one from South Africa. There have never been players from Russia, Mexico, Saudi Arabia and India.

4. Equivalent, at that time, to US\$ 155 million. countries that have contributed most with players, coaches and technical staff to the development of Chinese football ${ }^{3}$ have been Brazil and Argentina: certainly these two countries are the largest exporter of players around the world, however, by tradition and vocation, Brazilians have been more focused on Europe - almost 2/3 of them are concentrated in European leagues- while the geographic dispersion in the Argentine players is higher, as $55 \%$ are in Latin America, $36 \%$ in Europe and the rest in other regions. In other words, Argentine football seems more willing to explore new frontiers. In addition, as will be shown in the following lines, the interest of Argentineans in Chinese football is not reduced at the players level, but also covers the business and transcends the political.

\section{Argentina: a semi-peripheral state but "football world power"}

Argentina is a nation-state that throughout its history has had many ups and downs in its international position because, during almost two centuries (XVIII and XIX), it experienced moments of immense prosperity and growth -in which it arrived at to be the "world's breadbasket", the ninth world economic power and leader in the Latin American systembut then, in the twentieth century, experienced acute moments of recession, crisis and regression $(1930,1983,2001)$.

Precisely, a watershed in the contemporary history of Argentina is in the crisis of the end of 2001 and its repercussions in the following year. Vadell argues that "between 1998 and 2002, extreme poverty increased by $223 \%$ in Argentina. A unique data in such a small space of time. In 2001, the share of workers in GDP fell to the lowest level in Argentine history" (VADELL, 2006, p.202). By the end of 2002, the demands of Argentine society were becoming deeper. This complicated sociopolitical environment would lead to the presidential elections to advance almost six months from the scheduled date, and then to the unexpected election of Nestor Kirchner (2003-2007), who would inaugurate a left-progressive political cycle (the Kirchnerism) that would last for more than a decade with the governments of his wife, Cristina Fernandez de Kircher (2007-2015).

The political changes of the beginnings of the 21st century in Argentina also had an impact on the management of its local football (BECERRA, 2015). The former left-wing President Cristina Fernandez put into operation during 2009 the program Futbol Para Todos (FPT), which began to broadcast the Primera División games for free, with a state subsidy of 600 million Argentine pesos (ARP) ${ }^{4}$ per year (MIGUEZ, 2009); but, in the opposite direction, his successor Mauricio Macri annulled the state program FPT in its eighth year of operation and sold the broadcasting rights for the next 10 years to U.S. media companies Twenty-First Century Fox and Time Warner for a value of little more than US\$200 million per year (REUTERS STAFF, 2017), a greater amount than the Argentinean clubs received with FPT and presumably will come to revitalize the soccer business in this country for the next few years.

Despite the economic difficulties and political changes experienced by Argentina in recent decades, this has not prevented it from shining globally in terms of football for: having two of the most expensive teams 
on the American continent (River Plate and Boca Juniors) with a value exceeding $€ 50$ million; being the third most valuable league of western hemisphere (after Brazil and Mexico); being the place of birth of some of the players more costs of the world (today the most outstanding are Messi, Higuain, Aguero, Dybala and Icardi); being the country where more teams compete in a first division tournament ( 28 teams); because of the high competitiveness of its league, since in 2015 was considered the 4th strongest in the world (only after Spain, Italy and Germany); having some of the strongest clubs in the world such as River Plate, Boca Juniors, Racing Club, Students and San Lorenzo; having seven teams with a high brand value that places them among the "top 190" Brand Finance; being the fifth best national selection in all history, according to the FIFA ranking; and being the second exporter of soccer players (after Brazil), having contributed to the world "superstars" like Di Stefano, Kempes, Maradona, Batistuta and, at present, Messi. All this projects Argentina as an authentic "football world power", as evidenced by Table 1. But what is its specific contribution to the national power of Argentina?

In a pioneering study, both by their methodology and by their findings, Coremberg, Sanguinetti and Wierny calculated the contribution of professional and amateur football to Argentina's economy through direct effects (clubs and associated sectors) and indirect (suppliers, links with the national economy, etc.) of this sport. According to their estimates, Argentine football generated ARP\$41,775 million in 2013, of which ARP $\$ 8,860$ million correspond to the gross value created by the clubs and ARP\$ 32,915 million to the sectors that produce thanks to soccer. In the words of the authors, "this means that for each peso spent by clubs, an additional 3.7 pesos is generated in other sectors of the economy, more than calculated for the sport in the United Kingdom" (COREMBERG; SANGUINETTI; WIERNY, 2015, p.54). However, the most remarkable of this research is that it discovers the great potential of Argentine soccer because it "is competitive both football and economically (for its low costs) at an international level” (COREMBERG; SANGUINETTI; WIERNY, 2015, p.42), especially if it is taken into account that Argentine football clubs are mostly financed - almost 50\%- by their fans and not by the broadcasting rights, marketing and sponsorships as in Europe or Brazil.

This gives rise to enormous possibilities of understanding and collaboration between Argentina and China, which is potentially beneficial to both parties.

China, the new football's "emerging power"

According to Horne, although the official FIFA emblem "of two footballs imprinted with the map of the world depicts the Far East close to the center where the two balls intersect, there can be no doubt that Asia is peripheral in terms of football power" (HORNE, 2004, p.1235). However, in the last decade, this has begun to change substantially.

Same as the FIFA's report, the TV revenue from Asia and North Africa rose from USD $\$ 86$ million in 2007 to USD $\$ 218.2$ million in 2014, which represents a huge increase of the number of the fans in this certain 
region, which is undoubtedly the most dynamic region in the world. In this context, China stands. In the past few decades, China has devoted to surpass its situation of semi-peripheral country and has prepared itself to play a role as regional power. (EICHENGREEN, 2006; ARRIGHI, 2007). China is urged to improve itself from many different aspects, one of which is consolidate its influence, prestige and presence in globalization. Football happens to be a vital component of this because, in fact, China is an emerging country in this field and has much to grow (Table 1. The thrustfulness of football in regional powers). As Pulleiro pointed out, sports competition "supposes a sample of status and the acquired development in the existence of concrete power relations" (PULLEIRO, 2014, p.10).

According to the statistics of the IFFHS, the Chinese Super League (CSL) is considered to occupy the forth place among the football leagues in Asia, running after professional leagues of Korea, Saudi Arabia and Japan. However, the enhancement of competitiveness in recent years benefits from the sponsor of companies and the national project of building a football center. Besides, under the leadership of President Xi Jinping, revitalizing the Chinese football has been put on the agenda as a significant mission to create a sports world power. This goal will be achieved by getting into the FIFA World Cup (the one in 2002 was the only one in which the Chinese football team participated), host a FIFA World Cup in the year 2030 or 2034 and winning the World Cup before 2050.

It has been demonstrated that the promotion of sport does not necessarily translate into an increase in national capacities, even some academics have come to seriously debate the benefits of sporting megaevents for host countries (WHITSON; HORNE, 2006; BARCLAY, 2009; LI; MCCABE, 2013). However, China is shown as a paradigmatic case, completely opposite. According to Carlos Pulleiro, China has been able to use sport in each of the variants: "organizing the 2008 Summer Olympics to make visible its economic strength and ascendancy in the international power hierarchy, using ping-pong as a diplomatic element to establish contact with the United States or conditioning Taiwan's Olympic status on its return to Olympic Movement in the late seventies" (PULLEIRO, 2016, p.55). If a country has benefited politically from sport during the Cold War, it has been precisely China.

To achieve its goals in football, China needs to take three steps: first, expand the construction of the football field, including building more modern stadiums and increase the number of the football field all over the country. Second, pay more attention to the personnel training system, in other words, enhance the level of the Chinese local coaches and trainers. Third, Popularize the football, which CSL has begun to spend big-money in introducing famous European and South American football players to get the attention of Chinese fans and others worldwide.

Chinese Football Association was established in January 3, 1955, with only 62 years of history. The Argentine Football Association has set up for 124 years of and is the first of its kind in setting up in South America Football Association as well as one of the world's first eight Football Association. China is a sports power country, but not in football. In contrast, Argentina possesses richer experience. A few years after the 2014 FIFA World 
Cup, Argentina has been occupied the world's first position. China must use the power of predecessors to develop Chinese football. This year coincided with the 65th anniversary of the establishment of diplomatic relations between China and Argentina, China and Argentina will carry out more in-depth cooperation in various fields, especially in the field of football.

The level of the national football is determined by the football environment and the material conditions. China, with a complicated situation, is now facing countless difficulties in the development of football, which is restricted by the economic, the political and the cultural conditions. The CSL was established almost half a century later or more than the stronger leagues. The time was a little late. Besides, it has a slowing development because it lacks experience and it must face the impact of a political reform. China lagged other nations in the football development although China had done a lot since the establishment of the P.R.C. Not until the 1990s, did China begin to have its own professional league. Since 2001, the Chinese football became mired in corruption. The executives of the Association and the management of the club were involved in this scandal. Behaviors against the sports spirit like the match-fixing, the cheating calls and going on strike resulted in the devitalization of the Chinese football development. With a series of disclosed circumstances, the phenomenon of the football gambling gradually surfaced, involving the executives of the Association, the club management, the referee and the players. After the investigation and the punishment, in recent years, these bad behaviors have reduced a lot. On October 7, 2001, at the Wulihe Stadium in Shenyang, the Chinese national football team, under the leadership of Mi Lu, defeated Oman and historically stepped into the World Cup Finals. During that time, the football movement is gaining steam, with all the national team jersey sold out instantly. Primary and secondary schools also engaged specialty football training classes, showing that football had turned into the most popular sport. Although in that session, China was out without winning a game in the group, it had a huge positive effect on the domestic football environment. In recent years, the Guangzhou Evergrande Taobao Football Club won the AFC Asian Cup twice, making football heated again throughout the country. The future development of the Chinese football is worth looking forward to.

At the G-20 Hangzhou Summit in 2016, President Xi unexpectedly sent a request to the President Macri, hoping that China would have its own Messi or Maradona in 20 years, which would need the response of Argentina. Macri immediately responded that he was very glad to help. Then they also discussed on the issues like Argentine football coach teaching in China, Chinese players going to the Argentine club, etc.

Sino-argentine football relations

The football diplomacy proposed by President Xi has also become part of China's foreign policy. As the ping-pong diplomacy opened the door to Sino-American exchanges, football diplomacy aspires to narrow the distance between the Chinese people and the people of the world. Football diplomacy highlights China's open and inclusive diplomatic at- 
titude towards integrating into the world, reflects China's tentative "ball" diplomatic means to show China's humble and proactive big country style as well as China's reform goals of comprehensive development and flourishing. President Xi also put forward "Chinese Dream", the important guideline and ruling concept, with which the dream of sports power is also closely linked. Therefore, considering China's weak football performance, it is regarded as imperative to promote the reform of the football system. On February 27, 2015, the Central Leading Group for Comprehensive Deepening Reforms passed an overall program of China's football reform. The situation of Chinese football is changing.

On July 18, 2014, President Xi arrived in Buenos Aires for a state visit to Argentina and received No. 10 jersey of Argentine national team. After the Mayor Macri finished the gift-giving, Xi also humorously asked: "how much is the transfer fee?" During his visit to Argentina, President $\mathrm{Xi}$ repeatedly mentioned in his speech that he was eager to host the World Cup in China, hoping that Argentina would help Chinese football, causing great repercussions in the local football community.

With the increasingly close relations between China and Argentina, the Argentine clubs have gradually entered China, injecting vitality into the Chinese football development. At the same time, the Chinese companies also became sponsors of many well-known football clubs in Argentina. For example, Huawei has sponsored two famous clubs: the CA Boca Juniors and the River Plate. Many Argentine football clubs also carried out deeper cooperation in other fields in China. Chinese football should seize this opportunity to learn more about foreign advanced concepts and experiences.

The CSL has also introduced several Argentine football players, hoping that their power will help arouse the passion of the team. For example, in these two years, the Hebei China Fortune FC has introduced the Argentine international Ezequiel Ivan Lavezzi and the Shanghai Greenland Shenhua Football Club spent big-money in hiring Argentine players like Carlos Tevez. It will be easier to understand the big-money by counting that Tevez can earn US $\$ 80$ per minute. In addition to the transfer of the players, to get access to the Chinese market, Argentina and Brazil held the Supercopa Sudamericana in the Bird's Nest in Beijing, giving Chinese fans an opportunity to watch the competitions of famous football players like Messi, Neymar and Kaka at close range.

This year is the $65^{\text {th }}$ anniversary of the establishment of diplomatic ties between China and Argentina. The two countries will certainly consolidate and deepen bilateral cooperative relations, especially the cooperation in football. With the national determination to promote the football, both countries will seek for a mutually beneficial cooperation in various fields and attain sustainable development.

Conclusion

In previous lines, the challenges faced by China were analyzed, the most extraordinary emerging power since the end of the 20th century and the beginning of the 21st century, in its efforts to consolidate its national power using, as one more tool, football. The methodological 
strategy was, first, address a series of theoretical considerations to size the contribution of football to national power of a State; second, observe the potentiality of regional powers in this sport, but also their heterogeneity, specifically concerning Argentina -that represents a paradigmatic case that while maintaining itself as a semi-peripheral state, is at the same time a "football world power"- and China, an emerging power which understands soccer as a tool in the consolidation of its national power; third, a review of Sino-Argentine relations in this sporting matter.

The reasons that cause the differences between China and Argentina could be summarized as the following:

- Football system: The construction of the football system in China is a problem that needs more attention. Although several reforms have been conducted, the effect is not satisfactory. Additionally, along with the commercialization of football, the corruption began to appear again. What's worse, many club managers in the Chinese Football Association do not understand the football career resulting in a phenomenon that basically the professional subordinate staffs are under the charge of the unprofessional outsiders.

In Argentina, football can be seen everywhere. Greeting people by discussing the football is as normal as greeting with the question "Have you had your meal?" in China. According to the statistics, the penetration of football in Argentina is as high as $98 \%$ among the male from 3 to 70 years old. And 9 people out of 10 are club fans.

- Number of football population: the number of real Chinese football fans is not large, although in recent years the number has exploded. Some of them fall in love with football because of the World Cup while some fans get started because of the handsome football players. And some pay attention to football hearing of the report of the Chinese team's victory. The growth of fan's population doesn't seem healthy, but it still has a positive effect to some extent.

- Construction of the football infrastructure: Given that this densely populated country spans relatively little land, although the government keeps impelling the construction of athletic facilities, the demand of football field cannot be satisfied. Due to the high costs of the construction and the maintenance, some football field began to have an admission charge. Now it needs nearly 200 yuan for a cheap football game, too expensive for students with no income to play football, which indeed hinders the further development of the football career in China.

The situation is much better in Argentina. The Argentine football population is large, and people have begun to watch football games since they were young. The football infrastructure is adequate. There are 17 standard football fields in Buenos Aires, the capital of Argentina.

Considering this, it is easy to find out the huge possibility of the further communication between Argentina and China: the first has a strong football power which can be used smartly as a part of its public diplomatic means; the second needs the talents and experiences of coun- 
tries with a football tradition willing to support in the achievement of its national goals. In this aspect, Argentina and China are never competitors against each other.

References

ALLMERS, S.; MEANNIG, W. Economic impacts of the FIFA Soccer World Cups in France 1998, Germany 2006, and outlook for South Africa 2010. Eastern Economic Journal, v.35, n.4, p.500-519, 2009

ARRIGHI, G. Adam Smith en Pekin. Madrid: Akal, 2007

ASENIERO, G. Asia in the world-system. Social Justice, spring-summer, v.23, n.1/2 (63-64, p.28249, 1996

BARCLAY, J.. Predicting the cost and benefits of mega-sporting events: misjudgement of olympic proportions?. Economic Affairs, v.29, n.2, p.62-66, 2009

BARDON, S.; BLACK, M. The economics of sport in China: a maturing sector. China Perspectives, v.73, n.1, p.40-46, 2008

BECERRA, M.. Economía política de la pelota. Fútbol para Todos y el factor Tinelli. 2015 [Online] Available at: http://nuso.org/articulo/economia-politica-de-la-pelota/. Accessed sept. 2017

BECK, U. The cosmopolitan society and its enemies. Theory, Culture \& Society, v.19, n.1-2, p.1744, 2002

BEESON, M. Hegemonic transition in East Asia? The dynamics of chinese and american power. Review of International Studiesv.35, n.1, p.95-112, 2009

BONIFACE, P. El fútbol, fenómeno global por excelencia. Vanguardia Dossier, n.20, p.6-14, 2006

BRADLEY, J. M. The patriot game: football's famous 'Tartan Army'. International Review for the Sociology of Sport, v.37, n.2, p.177-197, 2002

BRAND FINANCE GROUP. Football Brands 2012. 2012 [Online]. Available at: http://brandfinance.com/images/upload/brandfinance_football_brands_2012.pdf. Accessed sept. 2017

CHASE-DUNN, C. Resistance to imperialism: semiperipheral actors. Review, Winter, n.XIII, v.1, p.1-31, 1990

CIES FOOTBAL OBSERVATORY. New exclusive CIES Football Observatory transfer value estimates. Neuchâtel: CIES Football Observatory, 2017

CORNNELL, J. Globalisation, soft power, and the rise of football in China. Geographical Research, sept., p.1-11, 2017

COREMBERG, A.; SANGUINETTI, J.; WIERNY, M.. La contribución del fútbol a la economía argentina. 2015 [Online].Available at: https://arklems.files.wordpress.com/2011/10/afafce-informe-final060415.pdf. Accessed sept. 2017

DARBY, P. Out of Africa: the exodus of elite african football talent to Europe. Journal of Laboratory Society, v.10, n.4), p.443-456, 2007

DARBY, P. 'Let us rally around the flag': football, nation-building, and pan-africanism in Kwame Nkumah's Ghana. Journal of African History, v.54, n.2, p.221-46, 2013

DIETSCHY, P. Making football global? FIFA, Europe, and the non-european football world, 1912-74. Journal of Global History, v.8, n.2, p.279-298, 2013

DUBAL, S. The neoliberalization of football: rethinking neoliberalism through the commercialization of the beautiful game. International Review for the Sociology of Sport, v.42, n.2, p.123146,2010

EICHENGREEN, B. China, Asia, and the world economy: the implications of an emerging asian core and periphery. China \& World Economy, v.14, n.3, p.1-18, 2006

EISENBERG, C. FIFA 1975-2000: the business of football development organisation. Historical Social Research, v.31, n.1, p. 55-68, 2006a

EISENBERG, C. International bibliography of football history. Historical Social Research, v.31, n.1, p.170-208, 2006b

EVENS, T.; LEFEVER, K.. Watching the football game: broadcasting rights for the european digital television market. Journal of Sport and Social Issues, v.35, n.1, p.33-49, 2011 
FALCONIERI, S., SÁKOVICS, J. ; PALOMINO, F.. Collective versus individual sale of television rights in league sports. Journal of the European Economic Association, v.2, n.5, p. 833-862, 2004

FIFA. Financial and governance report 2015.Ciudad de México: Fédération Internationale de Football Association, 2016

FIFA. Men's ranking. 2017 [Online] Available at: http://www.fifa.com/fifa-world-ranking/ranking-table/men/index.html.Accessed sept. 2017

FLEMES, D.. Conceptualizing regional power in international relations: lessons from the South African case. 2007 [Online]Available at: http://repec.giga-hamburg.de/pdf/giga_07_wp53_flemes.pdf. Accessed sept. 2017

FORBES. Los 20 equipos de futbol más valiosos de 2016. 2016. Available at: <ttps://is.gd/itTB20. Accessed: ago. 2017

FORBES. The world's 12 richest TV soccer deals. 2017 [Online]Available at: ttps://is.gd/7t1clU .Accessed sept. 2017

GASPARETTO, T.; BARAJAS, A. Reanalizando la competitividad en la industria del fútbol: diferencia acumulada de puntos. Revista de Administração de Empresas, v.56, n.3, p.288-301, 2016

GIRI, A. K. Cosmopolitanism and beyond: towards a multiverse of transformations. Development and Change, november, v.37, n.6, p.1277-1292, 2006

GORTAZAR, L. Broadcasting rights in football leagues and TV competition, Madrid: CEMFI, 2012

HADAS, M. Football and social identity: the case of Hungary in the Twentieth Century. The Sports Historian, v.20, n.2, p.43-66, 2000

HORNE, J. The global game of football: the 2002 World Cup and regional development in Japan. Third World Quaterly, v.25, n.7, p.1233-1244, 2004

HURRELL, A. Regional powers and a global system from a historical perspective. In: FLEMES, D. Regional leadership in the global system. Farnham: Ashgate, 2010

HUEVENNERS, C. Marketing of football broadcasting rights: is competition off-side?. 2014 [Online]. Available at: https://is.gd/79wBWo.Accessed sept. 2017

IFFHS. The strongest league in the world 2015. 2016a [Online]. Available at: http://iffhs.de/thestrongest-league-in-the-world-2015/. Accessed: abr. 2017

IFFHS. Club world ranking 2015. 2016b [Online]. Available at: http://iffhs.de/club-world-ranking-2015/. Accessed: abr. 2017

IFFHS,. International Federation of Football History and Statistics. 2017 [Online] Available at: http://iffhs.de/.Accessed sept. 2017

IÑIGUEZ-TORRES, L. P. Del desarrollo político-económico y la proyección internacional de Egipto tras la Guerra Fría: estrategias de una potencia subregional de Medio Oriente. InterNaciones, n.12, p.41-68, 2017

KARUSH, M. National identity in the sports pages: football and the mass media in 1920s Buenos Aires. The Americas, v.60, n.1, p.11-32, 2003

LEVERMORE, R. Sport-for-Development and the 2010 Football World Cup. Geography Compass, v.5, n.12, p.886-897, 2011

LI, S.; MCCABE, S. Measuring the socio-economic legacies of mega-events: concepts, propositions and indicators. International Journal of Tourism Research, v.15, n.4, p.388-402, 2013

MARKOVITS, A. Pourquoi n'y a-t-il pas de football aux États-Unis ? l'autre 'exceptionnalisme' américain. Vingtième Siècle, v.26, n.1, p.19-36, 1990

MARSCHIK, M. Mitropa: representations of 'Central Europe' in football. International Review for the Sociology of Sport, v.36, n.1, p.7-23, 2001

MEISSNER, F. \& VERTOVEC, S.. Comparing super-diversity. Ethnic and Racial Studies, v.38, n. 4 , p. $541-555,2015$

MIGUEZ, D.. Fútbol gratis por diez años en TV abierta. Página 12. 2009. Available at: https:// www.pagina12.com.ar/diario/elpais/1-130361-2009-08-21.html. Accessed: ago. 2017

MORALES, D., ROCHA, A. \& DURÁN, T.. Las potencias subregionales en el sistema internacional de Posguerra Fría: ¿nuevos actores en la política internacional?. Geopolítica(s), v.7, n.1, p.73-103, 2016.

MORALES, D., ROCHA, A. \& VARGAS, E.. Las potencias regionales como protagonistas del sistema político internacional: cooperación y diálogo en el Foro BRICS. Geopolítica(s), v.4, n. 2, p.237-261, 2013 
NOLTE, D. 2006. Potencias regionales en la politica internacional: conceptos y enfoques de análisis. 2006 [Online]. Available at: http://www.giga-hamburg.de/de/system/files/publications/wp30_ nolte.pdf. Accessed sept. 2017

POLI, R. Migrations and trade of african football players: historic, geographical and cultural aspects. Africa Spectrum, v.41, n.3, pp.393-414, 2006

POLI, R. ;RAVENEL, L. ; BESSON, R. Exporting countries in world football. Neuchâtel: CIES Football Observatory, 2015

POLI, R., RAVENEL, L. \& BESSON, R.. Transfer values and probabilities: the CIES Football Observatory approachNeuchâtel: CIES Football Observatory, 2016

PULLEIRO, C. Los Estados en los Juegos Olímpicos durante la Posguerra Fría desde la teoría del equilibrio de intereses: el caso de los BRICS. Trabajos y Ensayos, n.18, p.1-18, 2014

PULLEIRO, C.. Relaciones internacionales y Juegos Olímpicos. Bilbao: Centro de Estudios Olímpicos de la UPV/EHU, 2016

REUTERS STAFF. Fox, Turner win broadcast rights to Argentine soccer. Reuters, 2017. Available at: https://is.gd/LEWW1p. Accessed: ago. 2017

ROTTENBERG, S. The baseball players' labor market. The Journal of Political Economy, v.64, n.3, p.242-258, 1956

STOREY, D. Football, place and migration: foreign footballers in the FA Premier League. Geography, v.96, n.2, p.86-94, 2011

TAYLOR, M. Global players? Football, migration and globalization, c. 1930-2000. Historical Social Research, v.31, n. 1 (115), p.7-30, 2006

TAYLOR, P. J. \& FLINT, C. Geografía politica. Madrid: Trama Editorial, 2002

TERLOUW, K. Semi-peripheral developments: from world-systems to regions. Capitalism, Nature, Socialism, v.14, n.4, p.71-90, 2003

TIEN-CHIN, T. ; BAINER, A. Globalization and chinese sport policy: the case of elite football in the People's Republic of China. The China Quarterly, v.203, p.581-600, 2010

TORGLER, B.The economics of the FIFA Football Worldcup. Kyklos, v.57, n.2, p.287-300, 2004

$\begin{array}{lllllll}\text { TRANSFERMARKT } & \mathrm{GmbH} & \& & \mathrm{Co} & \text { Transfermarkt. } 2017 & \text { [Online] }\end{array}$ Available at: https://www.transfermarkt.es/

TZILI, E. Filipinas. Anuario Asia Pacifico, n.16, p.317-336, 2017

VADELL, J. A política internacional, a conjuntura econômica e a Argentina de Néstor

Kirchner. Revista Brasileira de Politica Internacional, v.49, n.1, p.194-214, 2006

VERTOVEC, S. Super-diversity and its implications. Ethnic and Racial Studies, v.30, n.6, p. 10241054,2007

WALLERSTEIN, I. The rise and future demise of the world capitalist system: concepts for comparative analysis. Comparative Studies in Society and History, v.16, n.4, p.387-415, 1974

WALLERSTEIN, I.. El moderno sistema mundial. Tomo I: la agricultura capitalista y los orígenes de la economía-mundo europea en el siglo XVI. México, D.F.: Siglo XXI. 2003

WALLERSTEIN, I. Northeast Asia in the multipolar world-system. Asian Perspective, v.34, n.4, p.191-205, 2010

WHITSON, D. \& HORNE, J.. Underestimated costs and overestimated benefits? Comparing the outcomes of sports mega-events in Canada and Japan. The Sociological Review, v.54, n.2, p.7389, 2006

ZOLO, D.Cosmópolis. Barcelona: Paidós, 2000 